\begin{tabular}{|l|l|l||}
\hline \multicolumn{2}{|c|}{ PublisherInfo } \\
\hline \hline PublisherName & $:$ & BioMed Central \\
\hline \hline PublisherLocation & $:$ & London \\
\hline \hline PublisherImprintName & $:$ & BioMed Central \\
\hline \hline
\end{tabular}

\title{
The silencing team
}

\begin{tabular}{|l|l|l||}
\hline \multicolumn{2}{|c|}{ ArticleInfo } \\
\hline \hline ArticleID & $:$ & 4443 \\
\hline \hline ArticleDOI & $:$ & $10.1186 /$ gb-spotlight-20020408-01 \\
\hline \hline ArticleCitationID & $:$ & spotlight-20020408-01 \\
\hline \hline ArticleSequenceNumber & $:$ & 109 \\
\hline \hline ArticleCategory & $:$ & Research news \\
\hline ArticleFirstPage & $:$ & 1 \\
\hline \hline ArticleLastPage & $:$ & 2 \\
\hline \hline & & RegistrationDate : 2002-4-8 \\
\hline ArticleHistory & $:$ & OnlineDate \\
\hline \hline ArticleCopyright & $:$ & BioMed Central Ltd2002-4-8 \\
\hline \hline ArticleGrants & $:$ & \\
\hline \hline ArticleContext & $:$ & 130593311 \\
\hline \hline
\end{tabular}




\section{Tudor Toma}

Email: t.toma@ic.ac.uk

Inactivation of tumor suppressor genes is an essential stage in the development of human cancer but the extent of involvement of epigenetic silencing and hypermethylation in this process remains unclear. In the April 4 issue of Nature, Ina Rhee and colleagues from Johns Hopkins University School of Medicine, show that two enzymes, DNMT1 and DNMT3b, cooperate to silence genes and maintain DNA methylation in human cancer cells.

Rhee et al. worked on a colorectal cancer cell line and observed that genetic disruption of both DNMT1 and DNMT3b eliminated nearly all methyltransferase activity and reduced genomic DNA methylation by greater than $95 \%$. This resulted in demethylation of repeated sequences, loss of insulinlike growth factor II (IGF2) imprinting, abrogation of silencing of the tumor suppressor gene p16INK4a and growth suppression (Nature 2002, 416:552-556).

These results "establish that methylation is essential for silencing tumor suppressor genes in human cancer cells. It will be of interest to determine whether these results apply to other human cell types," concluded the authors.

\section{References}

1. Rhee I, Bachman KE, Park BH, Jair KW, Yen RW, Schuebel KE, Cui H, Feinberg AP, Lengauer C, Kinzler KW, et al:: DNMT1 and DNMT3b cooperate to silence genes in human cancer cells. Nature 2002, 416:552-556., [http://www.nature.com]

2. InfoNet, Johns Hopkins University School of Medicine, [http://infonet.welch.jhu.edu/som/] 